\title{
Effects of Soil Moisture, Cultivar, and Postharvest Handling on Pillowy Fruit Disorder in Cucumber
}

\author{
John P. Navazio ${ }^{1}$ and Jack E. Staub ${ }^{2}$ \\ Vegetable Crops Research, U. S. Department of Agriculture, Agricultural Research Service, Horticulture \\ Department, University of Wisconsin, Madison WI 53706
}

Additional index words. Cucumis sativus, stomatal conductance, stress, drought, soil moisure tension

\begin{abstract}
Two experiments (1989 and 1990) were designed to characterize the response of cucumber (Cucumis sativus L.) plants with different leaf types [normal leaf $(L L)$ vs. little leaf $(l l)$ ] to high soil moisture tension (SMT) and to determine whether hydrocooling would reduce the severity of pillowy fruit disorder (PFD). Comparisons were made among nine cultivars $(7 \mathrm{LL}$ and $2 \mathrm{ll}$ ) for aboveground vegetative and fruit response, and between two irrigation regimes. High SMT generally caused increased wilt ratings and stomatal conductance and decreased plant dry weight. PFD severity of fruit from watered plots was less [61\% (Expt. 1, 1989) and 26\% (Expt. 1, 1990)] than of fruit harvested from plots in which water was withheld. The response of the two $l l$ cultivars to moisture stress differed depending on environmental conditions. Increased PFD severity was associated with increased temperature, lower relative humidity (RH), and excluding hydrocooling during postharvest handling. Of the four storage treatments examined, hydrocooling to $\approx 8.5 \mathrm{C}$ then storage at $15 \mathrm{C}$ and $85 \%$ RH for 4 days produced fruit with the least PFD symptoms. Fruit of 'Carolina' $(L L)$ exhibited the highest PFD ratings, while those of 'Calypso' $(L L)$ were consistently low compared to other cultivars. Processors can lower PFD incidence and severity by ensuring that adequate moisture is available to plants during fruit enlargement and that harvested fruit are hydrocooled before shipping and storage.
\end{abstract}

Cucumber vine growth, lateral branching, leaf area, fruit set, and growth rate are adversely affected when plants are subjected to soil moisture deficits (Cummins and Kretchman, 1975). Likewise, leaf water potential decreases with increases in soil moisture tension (SMT), resulting in reduced transpiration (Kramer, 1983; Krizek, 1985).

Fruit yield and quality are also affected by plant water stress. For example, pillowy fruit disorder (PFD) in cucumber is a waterand Ca-related anomaly (Staub et al., 1988; Thomas and Staub, 1992). PFD can be recognized when fruit are radially cut during grading before fresh-pack processing. PFD is typified by styrofoam-like, opaque-white, porous-textured mesocarp tissue in freshly harvested fruit. Affected regions become water-soaked and grayish-brown lesions appear in the overnight-refrigerated product, reducing its textural quality.

Staub et al. (1988) noted that the severity of PFD symptoms increases as mesocarp Ca levels decrease. When plant transpiration is restricted by high relative humidity $(\mathrm{RH})(89 \%)$, lower fruit $\mathrm{Ca}$ levels and a higher PFD incidence were observed compared to fruit that developed at lower (74\%) relative humidity (RH). Likewise, Thomas and Staub (1992) observed that PFD was more frequent and more severe (more mesocarp affected) in fruit harvested from treatments in which water was withheld compared to fruit from well-watered treatments.

Walters et al. (1990) conducted a series of experiments that compared the relative water content, osmotic potential, membrane leakage, cell wall composition, and PFD severity of fruit stored at high $(93 \%)$ and low (62\%) RH. Results indicate that fruit stored at $62 \% \mathrm{RH}$ lost weight more rapidly, showed a more rapid decline in relative water content and osmotic potential, and exhibited higher

Received for publication 4 Oct. 1993. Accepted for publication 20 June 1994 Mention of a trade name, proprietary product, or specific equipment does not constitute a guarantee or warranty by the U.S. Dept. of Agriculture and does not imply its approval to the exclusion of other products that may be suitable. The cost of publishing this paper was defrayed in part by the payment of page charges. Under postal regulations, this paper therefore must be hereby marked advertisement solely to indicate this fact.

${ }^{1}$ Former graduate research assistant.

${ }^{2}$ Research horticulturist and professor. levels of membrane leakage compared to fruit stored at $93 \% \mathrm{RH}$. Although fruit from both treatments developed PFD, it was more severe in fruit stored at $62 \% \mathrm{RH}$. Likewise, Thomas and Staub (1992) showed that PFD was more severe in fruit stored at 26.5C in either $60 \%$ or $75 \% \mathrm{RH}$ than in those stored at 10.5 or $15.5 \mathrm{C}$ and $85 \% \mathrm{RH}$. Results indicated that, of the postharvest handling regimes evaluated, $15.5 \mathrm{C}$ and $85 \% \mathrm{RH}$ minimized postharvest losses and 26.5C and 60\% RH produced the highest PFD level. Since only one genotype was evaluated by Thomas and Staub (1992) and the effect of hydrocooling on PFD symptomology has not been investigated, studies were undertaken to: 1) characterize plant response to water stress; 2) test whether genotypes possessing normal leaf size $(L L)$ and reduced leaf size $(l l)$ differ in response to soil moisture deficits; and 3) determine whether hydrocooling reduces PFD severity.

\section{Materials and Methods}

Water stress induction. Experiments were conducted at the Univ. of Wisconsin Research Station, Hancock, on a Plainfield loamy sand (Typic Updisamment; mixed mesic) in 1989 and 1990. In 1989 four and in 1990 eight cultivars were arranged in adjacent randomly assigned treatment plots (control and water withheld) $4.0 \mathrm{~m}$ apart. Each plot was divided into four $6.0-\mathrm{m}$ rows with end (0.6-m) and side (7.6-m) plot borders. Cucumbers were planted on $1.5-\mathrm{m}$ row centers and spaced $\approx 7.5 \mathrm{~cm}$ apart in the row $(89,000$ plants/ha). Standard fertilization, spraying, and hand cultivation was practiced in all experiments.

Each treatment (control and water withheld) row was portioned into four equal $1.2-\mathrm{m}$ segments, and cultivars were randomized in each of four replications within each treatment in a split-split-plot arrangement. In 1989, a replication consisted of a single row, while in 1990 two rows comprised a replication. Water stress treatment was the main plot and cultivar was the subplot in all analyses. For measurements taken once (plant harvest variables), an analysis of variance (ANOVA) was conducted using a split-plot design (spatial separation of watered and water-withheld plots). For measurements taken over time [daily stomatal conductance $\left(g_{s}\right)$ ], ANOVAs were performed using a split-split-plot model with time (day) as 
the sub-subplot factor nested within cultivar. Measurements were taken on plants of similar physiological maturity, and no plant was measured on 2 consecutive days. Mean separations were performed with Fisher's protected LSD at $P=0.05$ (Steel and Torrie, 1980).

Cucumber cultivars used in both experiments in 1989 were 'Flurry' (Asgrow Seed Co., Kalamazoo, Mich.), 'Calypso' (North Carolina Agricultural Experiment Station, Raleigh, N.C.), 'Carolina' (Clemson Agricultural Experiment Station, Clemson, S.C.), and the inbred line WI 1983 little leaf (ll) [U.S. Dept. of Agriculture, Agricultural Research Service(USDA-ARS), Madison, Wis.]. In 1990, the three normal leaf $(L L)$ (area of first fully expanded leaf 80 to $100 \mathrm{~cm}^{2}$; Staub et al., 1992) cultivars used in 1989 ('Flurry', 'Calypso', and 'Carolina') were evaluated along with 'Discover' (Asgrow Seed Co.), 'Endeavor' (USDA-ARS), 'Fancipak' (Asgrow Seed Co.), and the $l l$ cultivar H-19 (Univ. of Arkansas, Fayetteville, Ark.). The little leaf character (area of first fully expanded leaf 30 to $40 \mathrm{~cm}^{2}$; Staub et al., 1992) of H-19 and WI 1983 is derived from the same Univ. of Arkansas donor parent, AR 75-79 (ll).

SMT was monitored daily during stress periods using tensiometers (model 112; Irrometer Co., Riverside, Calif.) randomly placed in two rows of each treatment plot $23 \mathrm{~cm}$ deep. Control treatments received a minimum of $2.5 \mathrm{~cm}$ of water per week such that SMT did not exceed $28 \mathrm{kPa}$. To supplement natural precipitation, water was supplied through a zoned, drip irrigation system. Drip lines were placed $\approx 6.5 \mathrm{~cm}$ from the base of plants to provide similar amounts of water until water stress was initiated. Moveable rainout shelters were used during stress periods to protect treatments from precipitation. Treatment differences were examined by comparing linear $\left(b_{1}\right)$ and quadratic $\left(b_{2}\right)$ slope estimates for their equality (SMT and days taken as dependent and independent variables, respectively).

To compare physiological response to water stress, all fruit must be at the same developmental stage. Anthesis occurred in all cultivars within 3 to 4 days of each other, except for H-19, which flowered $\approx 10$ to 15 days later than the earliest flowering cultivar. To ensure synchronized fruiting among cultivars and across treatments, H-19 seeds were sown 12 days earlier than those of all other cultivars. Thus, plants in all treatment plots flowered simultaneously. At first harvest, fruit greater than $\approx 4 \mathrm{~cm}$ long were removed and the stress episode was initiated.

Daily visual ratings were taken between 13:00 and 15:00 HR during the stress episode based on a five-point scale: 1) loss of turgor resulting in recurved margins of leaves (i.e., downward cupping) between the base of the plant and the midvine; 2) leaves between the base of the plant and the midvine undulating and recurved; 3 ) $\approx 50 \%$ wilting of leaves from the base of the plant to the midvine; 4$) \approx 75 \%$ of the plant wilted from the base to the terminal whorl, and 5) complete wilting of leaves (100\%) from the base of the plant to the terminal whorl. The average degree of wilt for the entire stress period was calculated based on the daily degree of wilt and number of days that each cultivar remained wilted. During the stress period, stomatal resistance $\left(r_{s}\right)$, photosynthetic photon flux density (PPD), and ambient RH were measured daily between 10:00 and 14:00 HR when PPD was relatively high (1417 \pm 498 and $1318 \pm 399 \mathrm{mmol} \cdot \mathrm{m}^{-2} \cdot \mathrm{s}^{-1}$ in 1989 and 1990 , respectively).

Measurements of $r_{s}$ were taken on the fourth leaf from the terminal whorl of five randomly selected plants of each cultivar within a replication with a steady-state porometer (LI-1600; LI-COR, Lincoln, Neb.). These measurements were transformed to $\mathrm{g}_{\mathrm{s}}$ (mass to molar units) as $\mathrm{g}_{\mathrm{s}}=0.4 / \mathrm{r}_{\mathrm{s}}$ (Cowan, 1977), and control and water-withheld treatments were compared by modeling daily cultivar $g_{s}$ means as first- or second-order polynomials of time (days of water withheld) using regression. Treatment differences were examined by comparing linear $\left(b_{1}\right)$ and quadratic $\left(b_{2}\right)$ slope estimates for their equality. Readings of $g_{s}$ taken at the beginning and end of the stress episode divided by the number of days that water was withheld $\times 100 \%$ yielded a $\mathrm{g}_{\mathrm{s}}$ percent change value to compare cultivars.

Experiments ended when $30 \%$ to $40 \%$ of the fruit within a treatment were $\approx 3.2 \mathrm{~cm}$ in diameter $(2 \mathrm{~B}$ size). Fruit were harvested, average fruit number $(\mathrm{FN})$ and fruit weight $(\mathrm{FW})$ per plant were calculated, and aboveground plant organs (without the fruit) were harvested and dried at $60 \mathrm{C}$ for $72 \mathrm{~h}$ to determine average plant dry weight (DW). All mean values represent calculations made on a per-plot (replication) basis. Relative plant maturity was standardized with respect to flowering date and harvest time by staggering plantings (H-19 vs. other cultivars) and collecting data at the second harvest (synchronized for fruit development). To examine water stress and genotypic effects, these response variables were examined by ANOVA using a split-plot model. Water stress treatment was the whole-plot factor and was analyzed as a completely randomized design. Genotype effects were subplots nested within water stress and were analyzed as a randomized complete-block design.

Postharvest storage experiments. Harvested fruit were subjected to four postharvest regimes to simulate various conditions that might occur during commercial handling. Eighty fruit of each cultivar within each treatment were randomly selected $(\approx 1.9$ to 3.8 $\mathrm{cm}$ in diameter), partitioned into four groups, and held at $\approx 26 \mathrm{C}$ and $60 \% \mathrm{RH}$. Within $3 \mathrm{~h}$ of harvest, fruit from each treatment were placed in differing temperatures, $\mathrm{RHs}$, and storage durations ( 2 to 4 days) in controlled environments. Fruit were subjected to: 1) 4 days storage at $15 \mathrm{C}, 85 \% \mathrm{RH}$ [vapor pressure deficit $(\mathrm{VPD})=$ $0.249 \mathrm{kPa}]$ (cool temperature and high humidity); 2) hydrocooling to $\approx 8.5 \mathrm{C}$ within $60 \mathrm{~min}$ and storage at $15 \mathrm{C}, 85 \% \mathrm{RH}(\mathrm{VPD}=0.249$ $\mathrm{kPa}$ ) for 4 days (hydrocooling, cool temperature, and high humidity); 3) storage at $26 \mathrm{C}, 60 \% \mathrm{RH}(\mathrm{VPD}=1.298 \mathrm{kPa})$ for 1 day, then hydrocooling to $\approx 8.5 \mathrm{C}$ within $60 \mathrm{~min}$ and storage at $15 \mathrm{C}, 85 \% \mathrm{RH}$ $(\mathrm{VPD}=0.249 \mathrm{kPa}$ ) for 2 days (ambient conditions for $24 \mathrm{~h}$, then treatment 2), or; 4) 2 days storage at 26C, $60 \% \mathrm{RH}(\mathrm{VPD}=1.298$ $\mathrm{kPa}$ ) (ambient conditions).

Fruit temperature was measured using thermocouples $(0.003$

Table 1. Amount of wilting in four cucumber cultigens subjected to water stress in two experiments, Hancock, Wis., 1989.

\begin{tabular}{|c|c|c|c|c|}
\hline \multirow[b]{2}{*}{ Cultigen } & \multirow{2}{*}{$\begin{array}{c}\text { Treatment } \\
\text { duration } \\
(\text { days })^{\mathrm{z}}\end{array}$} & \multirow{2}{*}{$\begin{array}{l}\text { No. of days } \\
\text { plants } \\
\text { were wilted }\end{array}$} & \multicolumn{2}{|c|}{$\begin{array}{c}\text { Average wilt for } \\
\text { stress period }\end{array}$} \\
\hline & & & $\mathrm{X}^{\mathrm{y}}$ & SE \\
\hline \multicolumn{5}{|c|}{ Expt. 1} \\
\hline Flurry & 6 & 4 of 6 & 1.38 & 0.22 \\
\hline Calypso & 6 & 4 of 6 & 1.33 & 0.19 \\
\hline Carolina & 6 & 4 of 6 & 1.13 & 0.18 \\
\hline WI $1983^{x}$ & 6 & 0 of 6 & --- & --- \\
\hline \multicolumn{5}{|c|}{ Expt. 2} \\
\hline Flurry & 5 & 3 of 5 & 2.17 & 0.48 \\
\hline Calypso & 5 & 2 of 5 & 1.50 & 0.29 \\
\hline Carolina & 5 & 3 of 5 & 1.67 & 0.49 \\
\hline WI 1983 & 5 & 1 of 5 & 1.00 & 0.00 \\
\hline
\end{tabular}

${ }^{\mathrm{z} S t r e s s}$ treatment consisted of withholding soil moisture to cause wilting during second-harvest fruit enlargement.

${ }^{y}$ At least four replications of each cultigen.

${ }^{x}$ U.S. Dept. of Agriculture little leaf breeding line. 
$\mathrm{mm}$ in diameter) inserted into the midsection of the fruit 1.5 to $2 \mathrm{~cm}$ below the epidermis. Fruit were hydrocooled for $\approx 60 \mathrm{~min}$ with 7.7 $\pm 1.0 \mathrm{C}$ water until the internal fruit temperature was $8.5 \pm 1.1 \mathrm{C}$. Cooling trends were modeled with Newton's law of cooling: $\ln$ (fruit temperature - water temperature $)=a+b \times$ time $($ Thayer, 1953) using linear regression ( $\mathrm{a}$ and $\mathrm{b}$ are constants estimated from each data set). Cooling response $(\mathrm{y})$ was calculated as $\mathrm{y}=7.95-0.17 \times$ time $\left(R^{2}=\right.$ $0.69)$ and $y=10.6-0.20 \times$ time $\left(R^{2}=0.76\right)$ for hydrocooling in 1989 and 1990 , respectively. After postharvest storage, all fruit were halved in longitudinal sections and fresh-pack processed in brine solution supplied by Claussen Pickle Co., Woodstock, Ill.

Table 2. Amount of wilting in eight cucumber cultigens subjected to water stress in two experiments, Hancock, Wis., 1990.

\begin{tabular}{|c|c|c|c|c|}
\hline \multirow[b]{2}{*}{ Cultigen } & \multirow{2}{*}{ 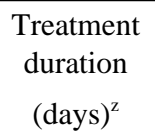 } & \multirow{2}{*}{$\begin{array}{l}\text { No. of days } \\
\text { plants } \\
\text { were wilted }\end{array}$} & \multicolumn{2}{|c|}{$\begin{array}{l}\text { Average wilt for } \\
\text { stress period }\end{array}$} \\
\hline & & & $\mathrm{X}^{\mathrm{y}}$ & SE \\
\hline \multicolumn{5}{|c|}{ Expt..1 } \\
\hline Flurry & 9 & 4 of 9 & 1.75 & 0.37 \\
\hline Calypso & 9 & 3 of 9 & 2.50 & 0.50 \\
\hline Carolina & 9 & 4 of 9 & 2.25 & 0.37 \\
\hline$H-19^{x}$ & 9 & 2 of 9 & 1.25 & 0.25 \\
\hline Endeavor & 9 & 4 of 9 & 2.25 & 0.45 \\
\hline Fancipak & 9 & 3 of 9 & 1.50 & 0.43 \\
\hline Discover & 9 & 3 of 9 & 2.17 & 0.48 \\
\hline Regal & 9 & 4 of 9 & 1.57 & 0.43 \\
\hline \multicolumn{5}{|c|}{ Expt. 2} \\
\hline Flurry & 8 & 2 of 8 & 0.50 & 0.22 \\
\hline Calypso & 8 & 2 of 8 & 1.00 & 0.58 \\
\hline Carolina & 8 & 2 of 8 & 1.80 & 0.66 \\
\hline H-19 & 8 & 1 of 8 & 0.50 & 0.29 \\
\hline Endeavor & 8 & 2 of 8 & 0.60 & 0.40 \\
\hline Fancipak & 8 & 1 of 8 & 0.67 & 0.33 \\
\hline Discover & 8 & 2 of 8 & 1.38 & 0.26 \\
\hline Regal & 8 & 2 of 8 & 1.00 & 0.37 \\
\hline
\end{tabular}

${ }^{\mathrm{z}}$ Stress treatment consisted of withholding soil moisture to cause wilting during second-harvest fruit enlargement.

${ }^{y}$ At least four replications of each cultigen.

${ }^{x}$ Univ. of Arkansas little leaf breeding line.
Processed cucumbers were held for 12 to 14 weeks at $8 \mathrm{C}$ before evaluation. Samples were evaluated for PFD severity by two groups of five industry representatives (judges) in each of 2 years. Judges were trained to recognize PFD symptoms just before examining processed samples. Fruit were classified as pillowed if opaque-white, porous-textured tissue was observed in the mesocarp region 2 to $6 \mathrm{~mm}$ under the epidermis. Fruit were given a percentage PFD value (percent longitudinal area showing pillowed tissue) by visual approximation according to Staub et al. (1988) and Thomas and Staub (1992). PFD symptoms were rated on a four-point scale, where 1 is $\geq 0 \% \leq 10 \%$ PFD, 2 is $\geq 10 \% \leq 20 \%$ PFD, 3 is $\geq 20 \% \leq 30 \%$ PFD, and 4 is $\geq 30 \% \leq 40 \%$ PFD.

ANOVAs and mean separations of pillowy evaluations were performed separately for each group of judges using a split-split-split-plot analysis. The whole-plot and split-plot factors were water stress and cultivar, respectively, with the sub-subplot factor of postharvest treatment nested within cultivar and the sub-sub-subplot factor of judges nested within postharvest treatment. Mean separations were performed with Fisher's protected LSD at $P=0.05$ (Steele and Torrie, 1980).

\section{Results}

Plants in well-watered treatments did not wilt. Wilting was recorded in all plots in which water was withheld except in one experiment (Tables 1 and 2). All cultivars, except WI 1983 (Expt. 1, 1989) exhibited some degree of wilting when water was withheld. Cultigen differences were recorded for the time to wilt threshold, number of days plants remained in a wilted condition, and average degree of wilt for the stress period. Little leaf cultivars (WI 1983 in 1989 and H-19 in 1990) were generally less susceptible to imposed water stress, as measured by these wilt variables, than normal leaf cultivars.

Water stress indices. Soil (SMT) and plant $\left(\mathrm{g}_{\mathrm{s}}, \mathrm{DW}, \mathrm{FN}\right.$, and FW) measurements supported visual wilt observations. Regression slope estimates of SMT values (linear $b_{1}$ values; Table 3) indicated that there were significant differences in soil moisture status between treatments after water was withheld. Although a significant increase in $\mathrm{SMT}\left(\mathrm{b}_{1}\right.$ value; $\left.P \leq 0.05\right)$ was recorded in the control plot of Expt. 1 in 1989, the daily mean SMT in control plots

Table 3. Daily mean soil moisture tension (kPa) and response estimates (regression) of cucumber subjected to water stress in four experiments, Hancock, Wis.

\begin{tabular}{|c|c|c|c|c|c|c|c|c|c|c|c|c|c|c|c|}
\hline \multirow[b]{2}{*}{ Expt. } & \multirow{2}{*}{$\begin{array}{l}\text { Water stress } \\
\text { treatment }^{\mathrm{y}}\end{array}$} & \multicolumn{11}{|c|}{ Treatment days } & \multicolumn{3}{|c|}{$\begin{array}{r}\text { Regression } \\
\text { estimates }^{z}\end{array}$} \\
\hline & & 1 & 2 & 3 & 4 & 5 & 6 & 7 & 8 & 9 & $\mathrm{X}^{\mathrm{x}}$ & SE & $\mathrm{b}_{1}$ & SE & $R^{2}$ \\
\hline \multicolumn{16}{|c|}{$1989^{w}$} \\
\hline \multirow[t]{2}{*}{ Expt. 1} & Control & 10.5 & 10.0 & 15.0 & 23.5 & 19.0 & 20.0 & --- & --- & --- & 16.3 & 2.22 & $2.37^{*}$ & 0.84 & 0.67 \\
\hline & Stress & 22.0 & 29.0 & 33.0 & 52.0 & 64.0 & 65.5 & --- & --- & --- & 44.3 & 7.65 & $9.76^{* *}$ & 1.13 & 0.95 \\
\hline \multirow[t]{3}{*}{ Expt. 2} & Control & 13.0 & 22.0 & 27.5 & 17.0 & 21.5 & --- & --- & --- & --- & 20.2 & 2.45 & 1.20 & 1.88 & 0.12 \\
\hline & Stress & 13.5 & 25.5 & 44.5 & 56.0 & 68.0 & --- & --- & --- & --- & 41.5 & 9.90 & $13.95^{\text {*** }}$ & 0.72 & 0.99 \\
\hline & \multicolumn{15}{|c|}{$1990^{w}$} \\
\hline \multirow[t]{2}{*}{ Expt. 1} & Control & 6.5 & 9.0 & 13.6 & 2.0 & 3.0 & 5.0 & 6.0 & 8.0 & 14.8 & 7.5 & 1.46 & 0.30 & 0.59 & 0.04 \\
\hline & Stress & 9.0 & 11.3 & 18.3 & 36.8 & 49.8 & 65.2 & 73.9 & 74.5 & 76.7 & 46.2 & 9.38 & $10.00^{* * * * *}$ & 0.90 & 0.95 \\
\hline \multirow[t]{2}{*}{ Expt. 2} & Control & 15.2 & 19.8 & 1.5 & --- & 1.2 & 3.2 & 5.0 & 6.0 & 10.8 & 7.8 & 2.27 & -0.96 & 0.87 & 0.17 \\
\hline & Stress & 7.7 & 14.7 & 22.5 & --- & 31.2 & 38.7 & 48.3 & 59.2 & 63.5 & 35.7 & 6.80 & $6.98^{* * * *}$ & 0.33 & 0.98 \\
\hline
\end{tabular}

${ }^{\mathrm{Z}}$ Regression slope inequality estimates between stress and control treatments were significant $(P \leq 0.001)$.

${ }^{y}$ Water stress treatments, where control equals sufficient soil moisture for growth and development and stress equals soil moisture withheld to cause wilting during second-harvest fruit enlargement.

${ }^{x}$ Mean of combined treatment days.

"Four cultigens were used in 1989 ('Flurry', 'Calypso', 'Carolina', and WI 1983) and eight were used in 1990 ('Flurry', 'Calypso', 'Carolina', H-19, 'Endeavor', 'Fancipak', 'Discover', and 'Regal').

***,*** Significant at $P=0.05,0.01$, or 0.001 , respectively. 
over both years was held below $28 \mathrm{kPa}$. In contrast, maximum SMT levels in water-withheld plots for all experiments ranged from 63.5 to $76.7 \mathrm{kPa}$. While the mean daily SMT in water-withheld

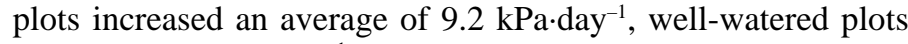
increased $1.3 \mathrm{kPa} \cdot \mathrm{day}^{-1}$. Slope inequality between control and water-withheld treatments for each experiment indicated significant differences in soil moisture depletion rates.

Plant response variables $\left(\mathrm{g}_{\mathrm{s}}, \mathrm{DW}, \mathrm{FN}\right.$, and $\left.\mathrm{FW}\right)$ indicated water stress (Tables 4 and 5). In most cases, significant $(P \leq 0.05)$ stress and cultivar main effects were observed for these plant measurement criteria. However, main effects of the stress treatment were not detected in Expt. 2 (1989) for $\mathrm{g}_{\mathrm{s}}, \mathrm{FN}$, and FW and in Expt. 2 (1990) for DW, FN, and FW. Likewise, significant cultivar main effects were not detected in Expt. 1 (1989) for DW and in Expt. 2 (1989) for $g_{s}$. Day main effects for $g_{s}$ were significant $(P \leq 0.001)$ in three of the four experiments (except Expt. 2, 1989). Two-way

Table 4. Cucumber plant response to soil water deficits in two experiments at Hancock, Wis., 1989.

\begin{tabular}{|c|c|c|c|c|c|c|c|c|}
\hline \multirow[b]{2}{*}{ Cultigen } & \multicolumn{4}{|c|}{ Expt. 1} & \multicolumn{4}{|c|}{ Expt. 2} \\
\hline & $\begin{array}{c}\text { Stomatal } \\
\text { conductance } \\
\left(\mathrm{mol} \cdot \mathrm{m}^{-2} \cdot \mathrm{s}^{-1}\right)^{\mathrm{z}}\end{array}$ & $\begin{array}{c}\text { Dry wt/ } \\
\text { plant } \\
(\mathrm{kg})^{\mathrm{y}}\end{array}$ & $\begin{array}{c}\text { Fruit } \\
\text { no./plant }\end{array}$ & $\begin{array}{l}\mathrm{Wt} / \\
\text { fruit } \\
(\mathrm{kg})\end{array}$ & $\begin{array}{c}\text { Stomatal } \\
\text { conductance } \\
\left(\mathrm{mol} \cdot \mathrm{m}^{-2} \cdot \mathrm{s}^{-1}\right)\end{array}$ & $\begin{array}{c}\text { Dry wt/ } \\
\text { plant } \\
(\mathrm{kg})\end{array}$ & $\begin{array}{c}\text { Fruit } \\
\text { no./plant }\end{array}$ & $\begin{array}{l}\mathrm{Wt} / \\
\text { fruit } \\
(\mathrm{kg})\end{array}$ \\
\hline \multicolumn{9}{|c|}{ Control } \\
\hline Flurry & 0.232 & 41.9 & 1.29 & 142.3 & 0.282 & 31.3 & 1.69 & 69.2 \\
\hline Calypso & 0.219 & 38.9 & 1.40 & 133.9 & 0.304 & 37.5 & 1.77 & 78.9 \\
\hline Carolina & 0.207 & 57.4 & 1.59 & 147.0 & 0.286 & 37.5 & 1.67 & 76.6 \\
\hline WI 1983 & 0.281 & 42.2 & 2.00 & 78.3 & 0.330 & 33.9 & 1.96 & 50.3 \\
\hline \multicolumn{9}{|c|}{ Stress $^{x}$} \\
\hline Flurry & 0.226 & 30.0 & 1.17 & 116.0 & 0.336 & 26.8 & 1.43 & 76.2 \\
\hline Calypso & 0.187 & 36.0 & 1.10 & 104.6 & 0.361 & 33.8 & 1.62 & 72.4 \\
\hline Carolina & 0.196 & 33.8 & 1.13 & 107.0 & 0.339 & 28.6 & 1.41 & 84.9 \\
\hline WI 1983 & 0.256 & 32.8 & 1.63 & 68.7 & 0.324 & 26.8 & 1.96 & 39.8 \\
\hline LSD (0.05) & 0.032 & 12.1 & 0.33 & 24.6 & 0.089 & 5.4 & 0.42 & 24.2 \\
\hline $\mathrm{CV}(\%)$ & 20.01 & 19.5 & 15.90 & 14.7 & 24.34 & 11.4 & 16.86 & 23.8 \\
\hline
\end{tabular}

${ }^{\mathrm{z}}$ Measurements taken $\approx 24 \mathrm{~h}$ before harvest (Table 1) between 10:00 and 14:00 HR.

yVegetative growth excluding fruit.

${ }^{x}$ Water stress treatments, where control equals sufficient soil moisture for growth and development and stress equals soil moisture withheld to cause wilting during second-harvest fruit enlargement.

Table 5. Cucumber plant response to soil water deficits in two experiments at Hancock, Wis., 1990.

\begin{tabular}{|c|c|c|c|c|c|c|c|c|}
\hline \multirow[b]{2}{*}{ Cultigen } & \multicolumn{4}{|c|}{ Expt. 1} & \multicolumn{4}{|c|}{ Expt. 2} \\
\hline & $\begin{array}{c}\text { Stomatal } \\
\text { conductance } \\
\left(\mathrm{mol} \cdot \mathrm{m}^{-2} \cdot \mathrm{s}^{-1}\right)^{\mathrm{z}}\end{array}$ & $\begin{array}{c}\text { Dry wt/ } \\
\text { plant } \\
(\mathrm{kg})^{\mathrm{y}}\end{array}$ & $\begin{array}{c}\text { Fruit } \\
\text { no./plant }\end{array}$ & $\begin{array}{l}\mathrm{Wt} / \\
\text { fruit } \\
(\mathrm{kg})\end{array}$ & $\begin{array}{c}\text { Stomatal } \\
\text { conductance } \\
\left(\mathrm{mol} \cdot \mathrm{m}^{-2} \cdot \mathrm{s}^{-1}\right)\end{array}$ & $\begin{array}{l}\text { Dry wt/ } \\
\text { plant } \\
(\mathrm{kg})\end{array}$ & $\begin{array}{c}\text { Fruit } \\
\text { no./plant }\end{array}$ & $\begin{array}{l}\mathrm{Wt} / \\
\text { fruit } \\
(\mathrm{kg})\end{array}$ \\
\hline \multicolumn{9}{|c|}{ Control } \\
\hline Flurry & 0.233 & 21.0 & 1.43 & 61.3 & 0.177 & 24.2 & 1.24 & 36.1 \\
\hline Calypso & 0.235 & 25.0 & 1.60 & 61.8 & 0.193 & 28.9 & 1.68 & 34.4 \\
\hline Carolina & 0.217 & 23.9 & 1.57 & 69.1 & 0.211 & 25.5 & 1.56 & 31.5 \\
\hline H-19 & 0.274 & 26.5 & 1.51 & 37.2 & 0.214 & 26.3 & 1.36 & 36.4 \\
\hline Endeavor & 0.233 & 26.6 & 1.55 & 68.2 & 0.218 & 31.1 & 1.65 & 35.2 \\
\hline Fancipak & 0.234 & 31.7 & 1.71 & 56.1 & 0.227 & 37.7 & 1.75 & 34.8 \\
\hline Discover & 0.231 & 21.8 & 1.43 & 57.8 & 0.190 & 24.8 & 1.34 & 27.1 \\
\hline Regal & 0.212 & 22.2 & 1.53 & 65.1 & 0.183 & 25.9 & 1.60 & 28.3 \\
\hline \multicolumn{9}{|c|}{ Stress $^{x}$} \\
\hline Flurry & 0.195 & 20.0 & 1.23 & 53.4 & 0.151 & 24.7 & 1.24 & 31.3 \\
\hline Calypso & 0.179 & 20.9 & 1.24 & 57.2 & 0.141 & 27.4 & 1.46 & 32.5 \\
\hline Carolina & 0.170 & 20.2 & 1.38 & 49.6 & 0.134 & 23.4 & 1.51 & 28.0 \\
\hline H-19 & 0.199 & 25.7 & 1.76 & 39.9 & 0.175 & 24.5 & 1.23 & 35.0 \\
\hline Endeavor & 0.183 & 22.1 & 1.46 & 55.2 & 0.155 & 29.0 & 1.64 & 35.8 \\
\hline Fancipak & 0.193 & 28.6 & 1.63 & 48.5 & 0.158 & 36.7 & 1.69 & 32.6 \\
\hline Discover & 0.180 & 19.3 & 1.36 & 58.1 & 0.138 & 24.0 & 1.23 & 26.7 \\
\hline Regal & 0.202 & 21.2 & 1.35 & 61.0 & 0.148 & 25.2 & 1.44 & 34.8 \\
\hline $\operatorname{LSD}(0.05)$ & 0.027 & 3.9 & 0.25 & 13.2 & 0.021 & 3.3 & 0.38 & 9.3 \\
\hline $\mathrm{CV}(\%)$ & 18.76 & 12.1 & 11.22 & 16.9 & 16.48 & 8.0 & 17.34 & 16.6 \\
\hline
\end{tabular}

${ }^{\mathrm{z}}$ Measurements taken $\approx 24$ h before harvest (Table 2) between 10:00 and 14:00 HR.

yegetative growth excluding fruit.

${ }^{x}$ Water stress treatments, where control equals sufficient soil moisture for growth and development and stress equals soil moisture withheld to cause wilting during second-harvest fruit enlargement. 
day $\times$ stress interactions were recorded in all four experiments.

Treatment differences $(P \leq 0.10)$ in $g_{s}$ rates as measured by daily mean $g_{s}$ slope inequality [ $b_{1}$ inequality $(1989)$ and $b_{2}$ inequality (1990)] were observed for all cultivars except 'Discover' and H-19 at least once over the course of the four experiments. No treatment differences (well-watered vs. water-withheld) for daily mean $g_{s}$ among cultivars were observed in Expt. 1 in 1990 (Fig. 1). In Expt. 1 (1989), the greatest difference in $\mathrm{g}_{\mathrm{s}}$ daily means between well-watered and water-withheld plots was recorded in 'Calypso' plots $(P=0.095)$ (data not presented). A difference in $\mathrm{g}$ between treatments was observed in WI 1983 by day 3 of the stress episode.
Greater differences between well-watered and water-withheld treatments were recorded in Expt. 2 (1989) compared to Expt. 1 (data not presented). 'Calypso' showed the greatest difference between treatments $(P=0.003)$ in mean daily $\mathrm{g}_{\mathrm{s}}$ followed by 'Carolina' ( $b_{1}$ inequality; $\left.P=0.034\right)$. Treatment differences among WI 1983 and 'Flurry' were also detected $(P=0.067$ and $P=0.081$, respectively). Differences between treatment means were largest in WI 1983 plots on the last day of the stress period (day 4). Although no differences in daily mean $\mathrm{g}_{\mathrm{s}}$ slope inequality were observed in Expt. 1, 1990 (Fig. 1), significant differences occurred between treatments for four of the eight cultivars tested in Expt. 2,

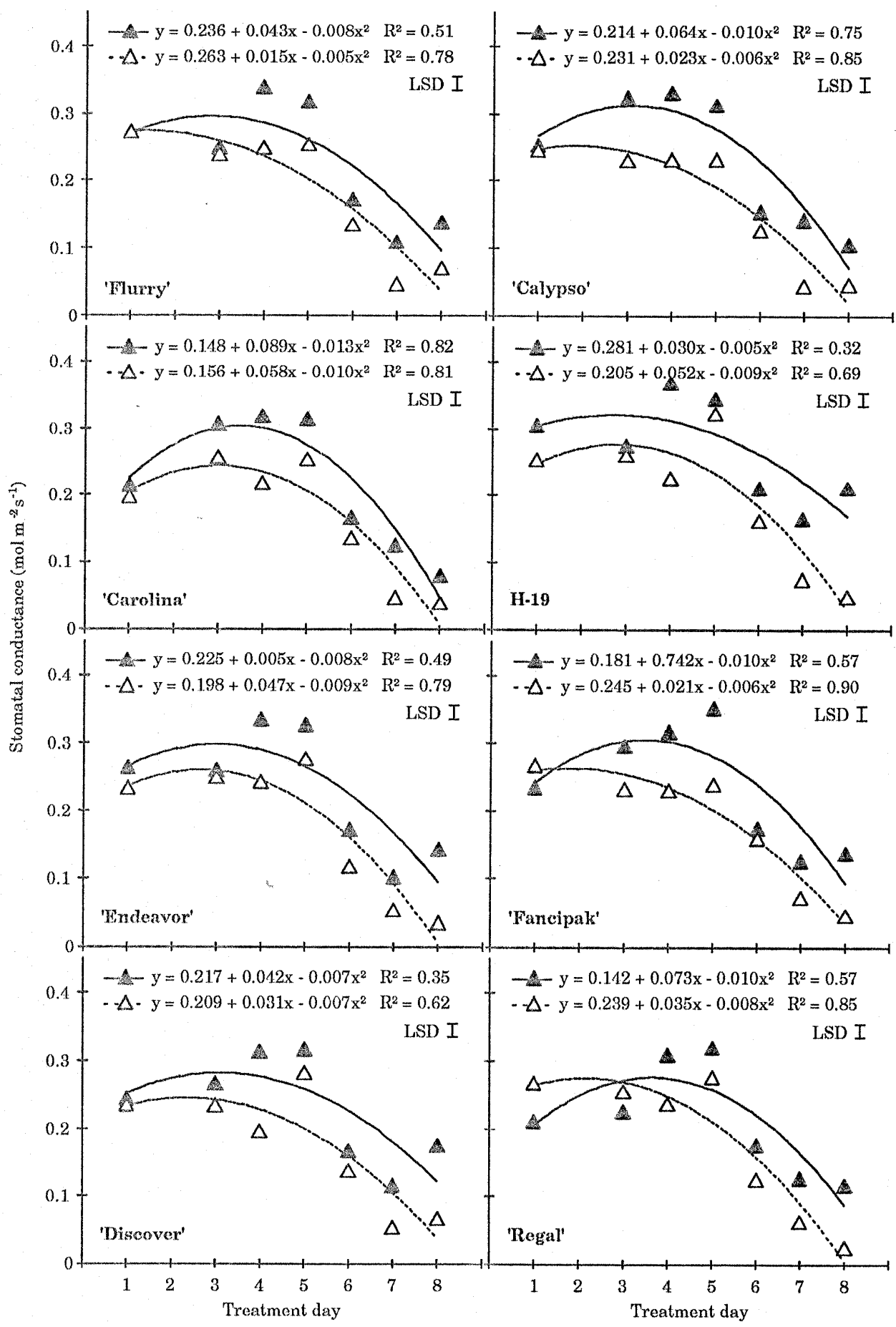

Fig. 1. Daily mean stomatal conductance $\left(\mathrm{mol} \cdot \mathrm{m}^{-2} \cdot \mathrm{s}^{-1}\right)$ for eight cucumber cultigens subjected to water stress, Expt. 1, Hancock, Wis., 1990; $\boldsymbol{\Delta}$ watered, $\Delta$ water withheld). Vertical bars represent LSD $(P=0.05)$. 
1990 (Fig. 2). 'Carolina' exhibited the largest daily mean $\mathrm{g}_{\mathrm{s}}$ treatment differences $\left(b_{2}\right.$ inequality; $\left.P=0.003\right)$. The next largest treatment differences in $\mathrm{g}_{\mathrm{s}}$ (slope inequality) were recorded for 'Endeavor' $(P=0.012)$, 'Fancipak' $(P=0.059)$, and 'Regal' $(P=$ 0.099).

DW in plants from water-withheld plots was always lower compared to plants harvested from well-watered plots, but not always significantly so (Tables 4 and 5). In 1989, DW reductions of 'Calypso' were less than those of 'Flurry' and 'Carolina', which were similar. In 1990 (Expt. 1), DW of 'Calypso' and 'Endeavor' in water-withheld plots was significantly less than in well-watered plots. DW differences of other cultivars were not significant. In
Expt. 2 (1990) there were no significant differences in DW between stress treatments.

While reductions in $\mathrm{FN}$ between stress treatments were recorded in Expt. 1, 1989 and 1990, no such differences were observed in Expt. 2 of either year (Tables 4 and 5). In 1989, the FN of 'Carolina' and WI 1983 in water withheld plots was significantly less than that of comparative plants in well-watered plots (Table 4). In 1990 (Expt. 1), FN harvested from 'Calypso' plants in water-withheld plots was significantly less than that harvested from 'Calypso' plants in well-watered plots. In Expt. 2 (1990) there were no FN differences between treatments (Table 5).

FW from plants in well-watered plots in Expt. 1 (1989) was

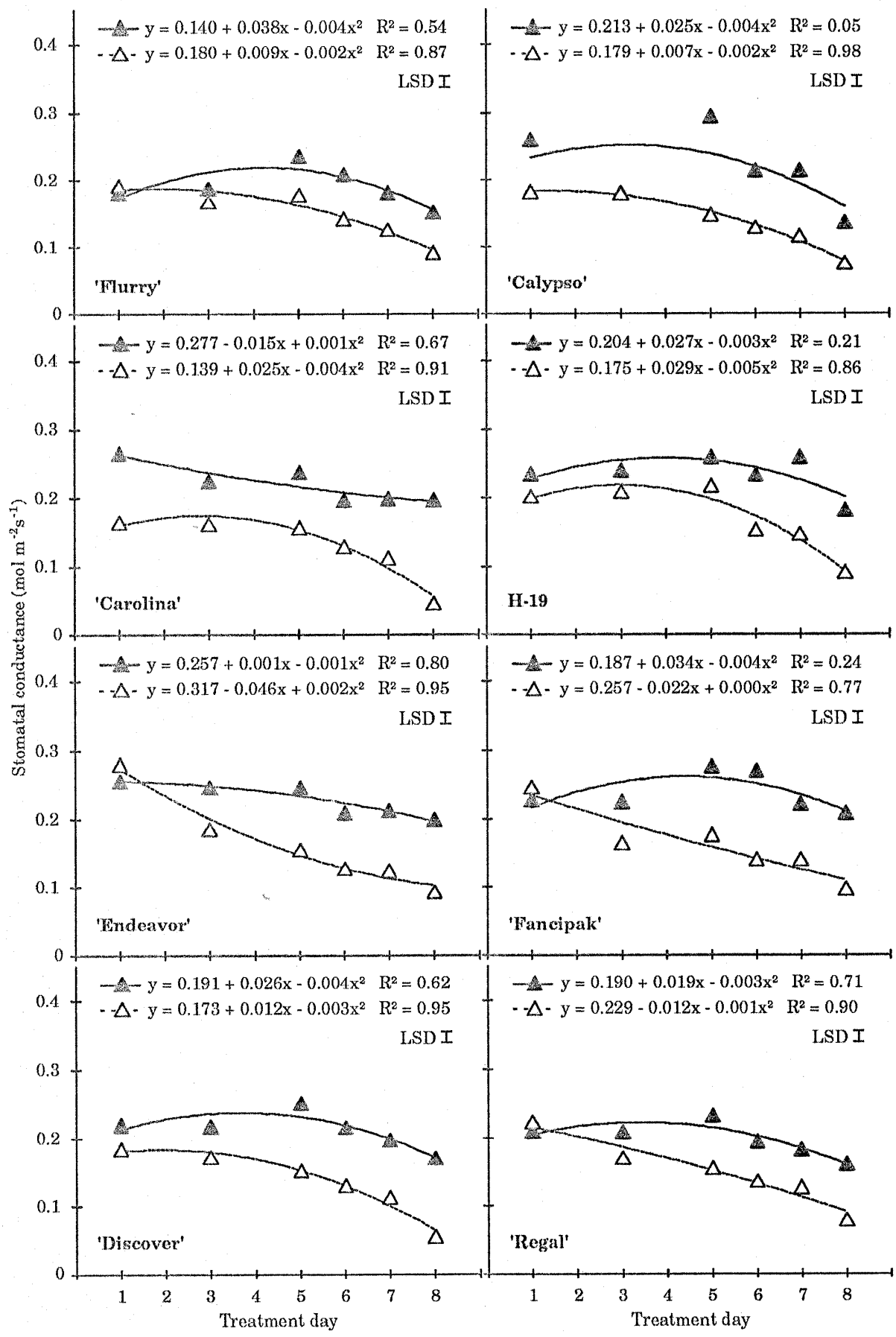

Fig. 2. Daily mean stomatal conductance $\left(\mathrm{mol} \cdot \mathrm{m}^{-2} \cdot \mathrm{s}^{-1}\right)$ for eight cucumber cultigens subjected to water stress, Expt. 2, Hancock, Wis., $1990 ; \boldsymbol{\Delta}$ watered, $\Delta$ water withheld). Vertical bars represent LSD $(P=0.05)$. 
significantly higher than in water-withheld plots for all cultivars, except WI 1983 (Table 4). In Expt. 2 (1989) FW differences between stress treatments were not significant for any cultivar tested. In 1990, cultivar differences in FW between stress treatments were detected in only one comparison ('Carolina') for Expts. 1 and 2 (Table 5).

Postharvest experiments. The main effects of stress on processed fruit quality as measured by PFD were significant in Expt. $1,1989(P \leq 0.001)$ and $1990(P \leq 0.05)$ (Table 6). Cultigen main effects were significant for Expts. 1 and $2(P \leq 0.05)$ in 1989 and for Expts. $1(P \leq 0.001)$ and $2(P \leq 0.05)$ in 1990 . No second-order cultivar interactions were detected in either year (data not presented). Postharvest treatment main effects were highly significant

Table 6. Mean pillowy fruit disorder ${ }^{\mathrm{z}}$ (PFD) ratings of processed fruit by five judges after preharvest water stress and postharvest storage treatments in controlled environments.

\begin{tabular}{|c|c|c|c|c|}
\hline \multirow[b]{3}{*}{ Source of variation } & \multicolumn{4}{|c|}{ PFD rating } \\
\hline & \multicolumn{2}{|c|}{1989} & \multicolumn{2}{|c|}{1990} \\
\hline & $1^{\mathrm{y}}$ & $2^{x}$ & 1 & 2 \\
\hline \multicolumn{5}{|l|}{ Judge } \\
\hline 1 & 2.56 & 0.86 & 2.48 & 3.42 \\
\hline 2 & 2.98 & 1.72 & 1.90 & 2.41 \\
\hline 3 & 2.52 & 0.97 & 2.35 & 2.62 \\
\hline 4 & 2.97 & 0.56 & 1.00 & 2.29 \\
\hline 5 & 2.17 & 1.19 & 2.98 & 1.95 \\
\hline LSD & 0.46 & 0.25 & 0.20 & 0.17 \\
\hline \multicolumn{5}{|c|}{ Water stress treatment ${ }^{\mathrm{w}}$} \\
\hline Control & 1.47 & 0.65 & 1.82 & 2.44 \\
\hline Stress & 3.77 & 1.47 & 2.46 & 2.63 \\
\hline LSD & 0.36 & 0.16 & 0.38 & 0.31 \\
\hline \multicolumn{5}{|c|}{ Postharvest treatment ${ }^{\mathrm{v}}$} \\
\hline 1 & 2.30 & 1.18 & 1.90 & 2.98 \\
\hline 2 & 2.22 & 0.66 & 1.75 & 2.21 \\
\hline 3 & 2.31 & 0.75 & 1.92 & 2.58 \\
\hline 4 & 3.71 & 1.65 & 3.00 & 2.37 \\
\hline LSD & 0.41 & 0.23 & 0.18 & 0.16 \\
\hline \multicolumn{5}{|l|}{ Cultigen } \\
\hline Flurry & 2.85 & 1.34 & 1.58 & 2.43 \\
\hline Calypso & 2.68 & 0.98 & 1.80 & 2.40 \\
\hline Carolina & 2.78 & 1.10 & 2.51 & 2.76 \\
\hline WI 1983/H-19 & 2.23 & 0.91 & 3.23 & 2.45 \\
\hline Endeavor & --- & --- & 2.16 & 2.72 \\
\hline Fancipak & --- & --- & 1.83 & 2.54 \\
\hline Discover & --- & --- & 1.85 & 2.40 \\
\hline Regal & --- & --- & 2.18 & 2.61 \\
\hline LSD & 0.41 & 0.23 & 0.26 & 0.22 \\
\hline $\mathrm{CV}$ & 49.31 & 68.79 & 54.53 & 39.61 \\
\hline
\end{tabular}

${ }^{\mathrm{z} P F D}$ was rated on a 10-point scale to represent the portion of fruit affected, where $0=0 \%$ to $9 \%, 1=10 \%$ to $19 \% \ldots 9=90 \%$ to $100 \%$.

'Experiment 1 (1989 and 1990) was conducted 1 to 15 Aug. each year. xExperiment 2 (1989 and 1990) was conducted 15 to 25 Aug. each year. ${ }^{w}$ Water stress treatments, where control equals sufficient soil moisture for growth and development and stress equals soil moisture withheld to cause wilting during second-harvest fruit enlargement.

'Postharvest storage treatments before processing: 1 (cool temperature, high humidity) $=4$ days at $15 \mathrm{C}, 85 \%$ relative humidity $(\mathrm{RH}) ; 2$ (hydrocooling, then cool temperature, high humidity) = hydrocooling to $\approx 10 \mathrm{C}, 4$ days at $15 \mathrm{C}, 85 \% \mathrm{RH} ; 3$ (ambient conditions for $24 \mathrm{~h}$, then treatment 2 ) $=1$ day at $26 \mathrm{C}, 60 \% \mathrm{RH}$, hydrocooling to $\approx 10 \mathrm{C}, 2$ days at $15 \mathrm{C}, 85 \% \mathrm{RH} ; 4$ (ambient conditions, control) $=2$ days at $26 \mathrm{C}, 60 \% \mathrm{RH}$. uLittle leaf cultigen used in 1989 and 1990 was WI 1983 and H-19, respectively.
$(P \leq 0.001)$ across all experiments (1989 and 1990) for PFD (data not presented). Main effects for judge were highly significant in all experiments. Several two-way judge interactions were detected in 1989 and 1990, including judge $\times$ stress, judge $\times$ cultivar, and judge $\times$ treatment. These second order interactions, however, were few and inconsistent. A three-way judge $\times$ stress $\times$ treatment interaction occurred in all four experiments.

Increased PFD severity was associated with increased temperature, lower RH, and absence of hydrocooling in postharvest storage. PFD ratings for control fruit (treatment 4, Table 6) after postharvest treatment were significantly higher than those for other postharvest treatments in three of the four experiments (except Expt. 2, 1990). Fruit stored in treatment 2 exhibited fewer PFD symptoms in all experiments (Table 6).

Individual cultivar differences with regard to PFD susceptibility varied between year. WI 1983 fruit exhibited the lowest PFD ratings in 1989, while 'Flurry' fruit displayed the highest PFD ratings (Table 6). In Expt. 1, 1990, H-19 fruit exhibited the highest PFD scores, while 'Flurry' fruit were given the lowest PFD ratings of the eight cultivars tested. 'Flurry', 'Discover', 'Calypso', and H-19 exhibited low PFD ratings. In contrast, 'Carolina' fruit were most affected by the various treatments across years, exhibiting relatively high PFD in three of the four experiments (Expt. 1, 1989; Expts. 1 and 2, 1990; Table 6).

\section{Discussion}

Thomas and Staub (1992) evaluated the effect of water stress and postharvest management without hydrocooling on the development of PFD in 'Calypso'. In this study, postharvest comparisons (four treatments) were made between fruit harvested from nine processing cucumber cultivars that had been subjected to water stress. These comparisons were made to determine if cultivars differ in susceptibility to PFD and if hydrocooling can decrease the severity of PFD below the optimal postharvest treatment used by Thomas and Staub (1992) (4 days storage at 15C, $85 \% \mathrm{RH})$.

Response to stress. Plants were adversely affected by the soil moisture deficits imposed in these experiments. The effects of increased SMT were in turn associated with increased PFD severity. These observations paralleled those of Thomas and Staub (1992), in which PFD frequency and severity were higher in fruit harvested from water-stressed plants (i.e., reduced photosynthesis and increased stomatal resistance and crop water stress index values) compared to well-watered controls. The fact that the plant parameters measured in this study were not always associated with PFD indicates that other factors are involved in pillowy development. It is known that temperature and RH also contribute to PFD development (Staub and Navazio, 1993).

The effects of imposed soil moisture deficits in all experiments were documented by at least three of the seven variables measured. In Expts. 1, 1989 and 1990, all seven plant variables documented the effects of soil moisture deficits in water-withheld plots (Tables $1,2,4,5$, and 6). In all experiments, $\mathrm{g}_{\mathrm{s}}$ values decreased in well-watered and water-withheld plots. The observed change in $g_{s}$ values among well-watered cucumber plants is a function of the aging process and fruit development (Nagoaka et al., 1984). Decreases in stomatal conductance in well-watered plots during stress episodes are consistent with those observed in greenhouse-grown cucumbers (Janoudi et al., 1993) and other crops (Davis et al., 1977) in which fruit enlargement occurred in nonstress environments.

SMT was relatively high by the last day of imposed stress in 
Expt. 2, 1989 and 1990 (day $5=68 \mathrm{kPa}$ in 1989 and day $8=63.5$ $\mathrm{kPa}$ in 1990). However, no differences in PFD were detected between fruit harvested from well-watered and water-withheld plots in either year. Irradiance and temperature could have affected PFD expression in these experiments, since these variables were lower than normal during the stress episodes. For example, during Expt. 2, 1990, the percent daily insolation $\left(\mathrm{MJ} \cdot \mathrm{m}^{-2} \cdot \mathrm{day}^{-1}\right)$ was below average for this time of year. The mean percent daily insolation during the stress period was $14.1 \mathrm{MJ} \cdot \mathrm{m}^{-2} \cdot \mathrm{day}^{-1} \mathrm{com}$ pared to the potential insolation mean of $23.6 \mathrm{MJ} \cdot \mathrm{m}^{-2} \cdot \mathrm{day}^{-1}$ for those days (estimates by the Univ. of Wisconsin Agricultural Weather Observation Network, Madison). The mean daily air temperature for the last 4 days of stress in Expt. 2, 1990, was relatively low compared to the 20-year mean for 1 to $15 \mathrm{Aug}$. (17.1 and $20.4 \mathrm{C}$, respectively). When irradiance and temperature were relatively high (e.g. Expt. 1, 1990), dramatic decreases in overall daily $g_{s}$ mean values and increases in 8-day percent change values of plants were recorded in water-withheld plots compared to experiments during which temperature and irradiance were lower than normal (Expt. 2, 1990). Such deviations (irradiance and temperature) from normalcy may partially explain why differences were not detected among water stress and postharvest treatments in Expt. 2, 1989 ( $\mathrm{g}, \mathrm{FN}, \mathrm{FW}$, and PFD) and in Expt. 2, 1990 (DW, FN, FW, and PFD). Such evidence documents the necessity of conditions optimal for plant growth and fruit development when studying PFD development.

Cultivar differences. Genotypic differences in susceptibility to Ca-related disorders has been reported in several crops (Johnson, 1991; Li and Gabelman, 1990). PFD is associated with low fruit Ca levels and is exacerbated by environmental stresses (Staub et al., 1988; Thomas and Staub, 1992). The cultivar differences (e.g., $l l$ vs. $L L$ ) in PFD observed in these experiments (Tables 4-6) concurs with previously observed variability in cultivar response to water stress and its concomitant influence on PFD (Staub et al., 1988). The current study extended the variables measured in the studies of Staub et al. (1988) and Thomas and Staub (1993) to include wilting ratings, $g_{s}, \mathrm{DW}$, and fruit yield. The relative cultivar ranking with regard to stress tolerance varied within and across experiments (e.g. 'Flurry' in Expt. 2, 1989, and Expt. 1, 1990), indicating that large genotype $\times$ environment interactions can affect the interpretation of PFD expression. Nevertheless, the reaction of certain cultivars to soil moisture deficits was consistent. For example, PFD severity in 'Calypso' fruit was consistently low compared to the other $L L$ cultivars tested. In contrast, the severity (intensity of visual symptoms) of PFD in fruit harvested from 'Carolina' plants subjected to water stress was greater than the other cultivars evaluated (Table 6; Expt. 1, 1989; Expts. 1 and 2, 1990).

Although WI 1983 and H-19 $(l l)$ are derived from AR 75-79, their response to soil water deficits differed depending on stress environment. WI 1983, had lower average wilt scores (Table 1) and higher average $g_{s}$ readings (Table 4) than $L L$ cultivars in the 1989 experiments, a result indicating a relatively high plant tolerance to the imposed stress. WI 1983 fruit also possessed significantly less PFD than $L L$ cultivars in Expt. 1 (Table 6). Likewise, H-19 exhibited a relatively high tolerance to high SMT levels in 1990 (Table 3). However, in Expt. 1 (1990), during which the plant variables measured indicated that stress levels were high, 'Flurry' and 'Fancipak' performed as well as 'Calypso' for fruit quality, while H-19's PFD symptoms were significantly higher than those of any $L L$ cultivar tested. When daily insolation levels and temperatures were low (Expt. 2, 1990), PFD differences between $\mathrm{H}-19$ and $L L$ cultivars were not detected. Thus, although a plant may not exhibit symptoms of stress during periods of soil water deficits (e.g., H-19, Expt. 1, 1990), it is possible that physiological responses may occur during incipient stress and cause poor fruit quality (i.e., cause and effect). Moreover, the inconsistent response of $l l$ cultivars to water stress over environments suggests that miniature leaf size may not be directly related to water-stress tolerance in cucumber (i.e., genetic background). The hypotheses as to cause and effect, and genetic background could be tested using nearly isogenic inbred lines differing in leaf size ( $l l$ vs. $L L)$.

Postharvest treatments. It is well known that removing field heat immediately after harvest enhances postharvest fruit quality (Kays, 1991). The optimum postharvest treatment of Thomas and Staub (1992; postharvest 1) approximates the industry practice of loading cucumbers directly into refrigerated trucks having a humidity saturating device for extended transport. A postharvest regime similar to treatment 4 is likely to occur in isolated production areas where hydrocooling is not available or refrigerated transport is unpredictable. This treatment equates to leaving fruit in ambient conditions for 2 days at a receiving station. Under what are often considered optimal conditions for freshly harvested cucumbers, fruit are hydrocooled for $60 \mathrm{~min}$ before being placed into refrigerated storage [similar to the optimum of Thomas and Staub (1992) but with hydrocooling; treatment 2] (Miller and Wehner, 1989). In our experiments, hydrocooling was added to the postharvest treatment that simulated the conditions under which fruit are left at ambient conditions in a packing shed (treatment 3; 1 day at $26 \mathrm{C}, 60 \% \mathrm{RH}$; then hydrocooling to $\approx 8.5 \mathrm{C}$, then 2 days at $15 \mathrm{C}, 85 \% \mathrm{RH})$. It is not uncommon at the peak harvest periods for fruit to be stored in a packing shed for 18 to $24 \mathrm{~h}$ before hydrocooling before shipping to a processing facility (R. Thomas, personal communication, 1993).

Our results confirm those of Thomas and Staub (1992), who found marked increases in PFD severity in fruit held at 26C and $60 \% \mathrm{RH}$ (treatment 4) compared to those stored at 15C and $85 \%$ $\mathrm{RH}$ (treatment 1). In all experiments, the superior postharvest treatment (treatment 2) involved hydrocooling immediately upon harvest, followed by the optimum storage conditions characterized by Thomas and Staub (1992) (15C and 85\% RH). Such a postharvest regime rapidly dissipates field heat from fruit (from $\approx 22.5$ to $\approx 8.5 \mathrm{C}$ in $60 \mathrm{~min}$ ) and controls transpirational water loss somewhat. PFD development is affected by fruit transpiration rate (Staub et al., 1988; Staub and Navazio, 1993). Treatment 2 undoubtedly slows the postharvest physiological changes that normally occur during fruit ripening and senescence, thus, decreasing the potential PFD severity (Salunkhe and Desai, 1984).

Our results suggest that there are several management practices that can be used to decrease PFD incidence and severity in field-grown cucumbers. Processors can lower PFD incidence and severity if adequate moisture is given to plants during fruit enlargement and harvested fruit are hydrocooled before shipping and storage. PFD severity may also be decreased by growing genotypes that are less susceptible to environmental stresses.

\section{Literature Cited}

Cowan, I.R. 1977. Stomatal behavior and environment. Adv. Bot. Res. 4:117-228.

Cummins, T.L. and D.W. Kretchman. 1975. Relation of internal water to growth and development of the pickling cucumber. HortScience 10:319. (Abstr.)

Davis, S.D., C.H.M. van Bavel, and K.J. McCree. 1977. Effect of leaf aging upon stomatal resistance in bean plants. Crop Sci. 17:640-645. Janoudi, A.K., I.E. Widders, and J.A. Flore. 1993. Water deficits and 
environmental factors affect photosynthesis in leaves of cucumber (Cucumis sativus). J. Amer. Soc. Hort. Sci. 118:366-370.

Johnson, J.R. 1991. Calcium nutrition and cultivar influence incidence of tipburn of collards. HortScience 26:544-546.

Kays, S.J. 1991. Postharvest physiology of perishable plant products. Van Nostrand Reinhold, New York.

Kramer, P.J. 1983. Water relations of plants. Academic Press, New York. Krizek, D.T. 1985. Methods of inducing water stress in plants. HortScience 20:1028-1038.

Li, Y. and W.R. Gabelman. 1990. Inheritance of calcium use efficiency in tomatoes grown under low-calcium stress. J. Amer. Soc. Hort. Sci. 115:835-838.

Miller, C.H. and T.C. Wehner. 1989. Cucumbers, p. 245-264. In: N.A.M. Eskin (ed.). Quality and preservation of vegetables. CRC Press, Boca Raton, Fla.

Nagoaka, M., K. Takahashi, and K. Arai. 1984. Effect of environmental factors on photosynthesis and transpiration of tomato and cucumber plants. Veg. and Ornamental Crops Res. Sta. Bul. 12. p. 97 117.
Salunkhe, D.K. and B.B. Desai. 1984. Postharvest biotechnology of vegetables. vol. 2. CRC Press, Boca Raton, Fla.

Staub, J.E., L.D. Knerr, and H.J. Hopen. 1992. Plant density and herbicides affect cucumber productivity. J. Amer. Soc. Hort. Sci. 117:48-53.

Staub, J.E. and J.P. Navazio. 1993. Temperature and humidity affect pillowy fruit disorder in cucumber. HortScience 28:822-823.

Staub, J.E., P. Rousos, and B.E. Struckmeyer. 1988. Anatomical characterization and possible role of calcium in "pillowy," a fruit disorder in processing cucumber. J. Amer. Soc. Hort. Sci. 113:905-909.

Steel, R. and J.H. Torrie. 1980. Principles and procedures of statistics. 2nd ed. McGraw-Hill, New York.

Thayer, H.S. 1953. Newton's philosophy of nature: Selections from his writings, edited and arranged with notes. Hafner, New York.

Thomas, R.S. and J.E. Staub. 1992. Water stress and storage environment affect pillowy fruit disorder in cucumber. J. Amer. Soc. Hort. Sci. 117:394-399.

Walters, Jr., W.M., D.G. Epley, and R.F. McFeeters. 1990. Effect of water stress on stored pickling cucumbers. J. Agr. Food Chem. 38:2185-2191. 